\title{
Ghrelin system is involved in improvements in glucose metabolism mediated by hyperbaric oxygen treatment in a streptozotocin-induced type 1 diabetes mouse model
}

\author{
LIMIN SONG $^{1 *}$, JUNHUA YUAN ${ }^{1 *}$, YUAN LIU $^{1}$, DI ZHANG ${ }^{1}$, CAISHUN ZHANG $^{1}$, QIAN LIN $^{1}$, \\ MANWEN $\mathrm{LI}^{1}$, KAIZHEN SU ${ }^{2}$, YANRUN $\mathrm{LI}^{2}$, GUANGKAI GAO ${ }^{3}$, RUIXIA MA ${ }^{4}$ and JING DONG ${ }^{1,5}$ \\ Departments of ${ }^{1}$ Special Medicine and ${ }^{2}$ Clinical Medicine, Medical College, Qingdao University, \\ Qingdao, Shandong 266071; ${ }^{3}$ Department of Hyperbaric Medicine, Hospital of Chinese People's Liberation Army, \\ Qingdao, Shandong 266072; ${ }^{4}$ Department of Nephrology, Affiliated Hospital of Qingdao University, Qingdao,
} Shandong 266005; ${ }^{5}$ Department of Physiology, Medical College, Qingdao University, Qingdao, Shandong 266071, P.R. China

Received April 23, 2020; Accepted July 28, 2020

DOI: $10.3892 / \mathrm{mmr} .2020 .11481$

\begin{abstract}
Type 1 diabetes mellitus (T1DM) is an autoimmune disorder for which the only effective therapy is insulin replacement. Hyperbaric oxygen (HBO) therapy has demonstrated potential in improving hyperglycemia and as a treatment option for T1DM. Ghrelin and HBO have been previously reported to exert proliferative, anti-apoptotic and anti-inflammatory effects in pancreatic cells. The present study investigated the mechanism underlying HBO- and ghrelin system-mediated regulation of glucose metabolism. Male C57BL/6 mice were intraperitoneally injected with streptozotocin (STZ; $150 \mathrm{mg} / \mathrm{kg}$ ) to induce T1DM before the diabetic mice were randomly assigned into the T1DM and T1DM + $\mathrm{HBO}$ groups. Mice in the T1DM + HBO group received HBO ( $1 \mathrm{~h} ; 100 \%$ oxygen; 2 atmospheres absolute) daily for 2 weeks. Significantly lower blood glucose levels and food intake were observed in mice in the T1DM + HBO group. Following HBO treatment, islet $\beta$-cell area were increased whereas those of $\alpha$-cell were decreased in the pancreas. In addition, greater hepatic glycogen storage in liver was observed, which coincided with higher pancreatic glucose transporter 2 (GLUT2) expression levels and reduced hepatic GLUT2 membrane trafficking. There were also substantially higher total plasma ghrelin concentrations and gastric ghrelin-O-acyl transferase (GOAT) expression levels in mice in the T1DM + HBO group. $\mathrm{HBO}$ treatment also abolished reductions in pancreatic GOAT
\end{abstract}

Correspondence to: Professor Jing Dong, Department of Physiology, Medical College, Qingdao University, 308 Ningxia Road, Qingdao, Shandong 266071, P.R. China

E-mail: dongjing6@hotmail.com

*Contributed equally

Key words: hyperbaric oxygen, type 1 diabetes, ghrelin, ghrelin-O-acyl transferase, growth hormone secretagogue receptor expression levels in T1DM mice. Additionally, hepatic growth hormone secretagogue receptor-1a levels were found to be lower in mice in the T1DM + HBO group compared with those in the T1DM group. These results suggest that HBO administration improved glucose metabolism in a STZ-induced T1DM mouse model. The underlying mechanism involves improved insulin-release, glucose-sensing and regulation of hepatic glycogen storage, an observation that was also likely dependent on the ghrelin signalling system.

\section{Introduction}

Type 1 diabetes mellitus (T1DM) is a chronic metabolic disorder that is characterized by the destruction of islet $\beta$-cells and lack of insulin production (1). The progressive dysfunction and decline in $\beta$-cell mass results in patients relying on exogenous insulin to maintain glucose homeostasis. However, achieving strict daily glycemic control is difficult for many patients $(1,2)$.

Due to its safe and non-invasive nature, hyperbaric oxygen (HBO) treatment has emerged since the 1990s as a potential alternative treatment strategy for autoimmune diseases (3). HBO has been demonstrated to exhibit anti-inflammatory properties (4), such as mobilizing bone marrow stem cells and activating the antioxidant enzyme system to improve tissue defense (5-7). Clinical studies have previously revealed the improvement of hyperglycaemia in patients with diabetes undergoing $\mathrm{HBO}$ treatment $(8,9)$. HBO has also been reported to prevent hyperglycaemia and improve muscle oxidative capacity in rodents with T2DM $(10,11)$. Faleo et al (12) found that 2 -week HBO treatment preserved islet $\beta$-cell mass by stimulating proliferation, inhibiting apoptosis and suppressing insulitis, thus decreasing the incidence of autoimmune diabetes in non-obese diabetic mice. Nevertheless, the mechanism of action underlying the effects of HBO has not yet been fully elucidated. In addition to the pancreas, the liver is also an important organ for maintaining blood glucose balance by storing glucose as glycogen and releasing glucose by glycogen degradation and gluconeogenesis (13). However, to date it 
remains unclear whether $\mathrm{HBO}$ exhibits a therapeutic effect on liver glycogen storage and glucose production in T1DM.

The ghrelin system consists of four components: Ghrelin, ghrelin-O-acyl transferase (GOAT), growth hormone secretagogue receptor-1a (GHSR) and liver expressed antimicrobial peptide 2 (LEAP2) $(14,15)$. Ghrelin is a 28 -amino acid peptide that is secreted primarily by the stomach as the endogenous ligand for GHSR $(16,17)$, whilst LEAP2 is the endogenous antagonist of GHSR (15). Ghrelin possesses a unique post-translational modification where it is $\mathrm{O}$-acylated at its serine 3 residue by GOAT, which is necessary for binding to GHSR (18). The ghrelin system serves a key role in regulating energy metabolism. Zhao et al (19) previously demonstrated that it is essential for mouse survival during calory restriction. Ghrelin has also been found to suppress inflammation, exert immunoregulatory (20-22) and anti-edematous effects in the context of brain hypoxia $(23,24)$. Ghrelin, GOAT and GHSR are all expressed in pancreatic islet cells, suggesting that ghrelin mediates physiological effects on the pancreas via paracrine or autocrine pathways $(25,26)$. A number of studies have demonstrated that ghrelin stimulates proliferation whilst inhibiting apoptosis to protect cells, such as retinal ganglion cells and osteoblastic MC3T3-E1 cells (27-30). In particular, it has also been demonstrated that overexpression of intra-islet ghrelin increases the proliferation of islet $\beta$-cells in a streptozotocin (STZ)-induced $\beta$-cell injury model (31). Exogenous injection of ghrelin has been demonstrated to delay the development of autoimmune diabetes by mitigating insulitis and $\beta$-cell mass loss in BioBreeding/Worcester rats (32). Furthermore, certain studies have found that ghrelin regulates GLUT2 expression $(33,34)$ and stimulate hepatic gluconeogenesis (35).

Since both ghrelin and HBO therapy have been documented to stimulate proliferation and exhibits anti-inflammation and anti-edematous effects, it was investigated whether $\mathrm{HBO}$ influenced circulating ghrelin levels, in addition to GOAT and GHSR protein expression in the pancreas and liver of T1DM mice.

The present study aimed to investigate the mechanism underlying the amelioration of hyperglycemia induced by T1DM following 2-week HBO treatment. Subsequently, it was further investigated if the ghrelin system lie downstream of HBO treatment.

\section{Materials and methods}

Animals. A total of 20 C57BL/6J male mice (age, 8 weeks; weight, 27-31 g) were obtained from Qingdao Institute of Drug Control (Qingdao, China), and were acclimatized at the animal facility $\left(21-25^{\circ} \mathrm{C} ; 55 \pm 20 \%\right.$ humidity; 12-h light/dark cycle) in specific pathogen-free conditions with ad libitum access to food and water for 1 week prior to experimentation.

To establish a T1DM mouse model, 15 mice were intraperitoneally (i.p.) injected with STZ $(150 \mathrm{mg} / \mathrm{kg}) 12 \mathrm{~h}$ after fasting (36), whilst the other five mice received an equivalent volume $(7.5 \mathrm{ml} / \mathrm{kg})$ of citrate buffer. After 7 days, blood glucose levels were measured from tail vein blood $(\sim 50 \mu \mathrm{l})$ using a glucometer (B. Braun Melsungen AG). All mice exhibiting random blood glucose $\geq 16.7 \mathrm{mmol} / 1$ accompanied by excessive drinking, eating, urination and weight loss were considered to be type 1 diabetic (37). These mice were then randomly divided into three groups: i) Control (CON, $n=5)$; ii) T1DM (n=8); and iii) T1DM + HBO $(n=7)$.

Animals were sacrificed following the final HBO treatment by exsanguination following anaesthesia via an i.p. injection of sodium pentobarbital $(50 \mathrm{mg} / \mathrm{kg})$. The tail of the pancreas and liver were then fixed in $4 \%$ paraformaldehyde at $4^{\circ} \mathrm{C}$ for $24 \mathrm{~h}$ and embedded in paraffin and sectioned at $5 \mu \mathrm{m}$ for histology assessment. Other samples of pancreas, liver and stomach tissue were stored at $-80^{\circ} \mathrm{C}$ for western blotting. Heparin sodium salt (cat. no. H8060-1g; Beijing Solarbio Science \& Technology Co., Ltd.) was added to the blood samples as an anticoagulant, following which the blood was centrifuged using a refrigerated centrifuge (Eppendorf) to obtain the plasma $\left(4^{\circ} \mathrm{C}, 20,000 \mathrm{x} \mathrm{g}, 15 \mathrm{~min}\right)$. Plasma samples were stored at $-20^{\circ} \mathrm{C}$ for further analysis.

$\mathrm{HBO}$ treatment. HBO treatment was performed once per day for 2 weeks. Briefly, mice were transferred into the animal hyperbaric oxygen chamber, which was $\sim 40 \times 100 \mathrm{~cm}$ in size (Yantai Moon Oxygen Chamber Co., Ltd.) at 7:00 p.m. Mice in the CON and T1DM groups were placed into a hyperbaric oxygen chamber without HBO treatment. The hyperbaric session began with pressure rising gradually over a 5-min period, followed by continuous exposure to $100 \%$ oxygen at 2.0 atmospheres absolute (ATA) for $60 \mathrm{~min}$. The chamber pressure was then gradually decreased over another 5-min period before opening (12).

Cumulative food intake and body weight. On day 12 of HBO treatment, cumulative food intake was measured. Food deprivation began at 2:00 p.m on day 12 and mice were fasted for $5 \mathrm{~h}$. Following 1-h HBO treatment, mice were fed and cumulative food intake was measured using an electronic scale (cat. no. TE412-L; Sartorius AG) 1, 2, 3, 4, 5, 6 and $12 \mathrm{~h}$ after HBO treatment as previously described (38). During the HBO treatment, body weight was measured every day for 11 days, except for the day of the feeding and blood glucose testing to avoid the influence of fasting.

Blood glucose and ghrelin levels. At the end of 2-week treatment cycle, blood glucose levels were measured from tail vein blood using a glucometer (B. Braun Melsungen AG) following fasting for $10 \mathrm{~h}$. The mice were then re-fed for $2 \mathrm{~h}$ before blood samples $(\sim 1 \mathrm{ml})$ were immediately obtained from the inner canthus of mice for total plasma ghrelin testing and subsequent sacrifice. Plasma total ghrelin levels were measured using a mouse ultrasensitive ELISA kit (cat. no. CEA991Mu; Wuhan USCN Business Co., Ltd.) according to the manufacturer's protocols.

Histological processing. Pancreas and liver tissues were fixed in $4 \%$ formaldehyde at $4^{\circ} \mathrm{C}$ for $48 \mathrm{~h}$. Following dehydration with an ascending gradient of ethanol and clearing with xylene, tissues were embedded in paraffin and sectioned at $5 \mu \mathrm{m}$ using a rotary microtome (RM2016; Leica Microsystems GmbH).

Periodic acid-Schiff (PAS) staining. Hepatic sections were stained using a PAS Staining kit (cat. no. G1008; Wuhan Servicebio Technology Co., Ltd.) to observe glycogen 
distribution according to the manufacturer's protocols. Randomly selected hepatic sections were disposed with $\alpha$-amylase at $37^{\circ} \mathrm{C}$ for $30 \mathrm{~min}$ before PAS staining, and used as the negative control group (cat. no. G8290; Beijing Solarbio Science \& Technology Co., Ltd.) prior to PAS staining for $30 \mathrm{~min}$ at $37^{\circ} \mathrm{C}$.

Immunohistochemistry. Following antigen retrieval by heating at $95^{\circ} \mathrm{C}$ in citrate buffer for $1 \mathrm{~h}$, the pancreas and liver sections were quenched with $0.3 \%$ hydrogen peroxide at room temperature for $30 \mathrm{~min}$, blocked with $1 \%$ BSA (cat. no. 1213G057; Beijing Solarbio Science \& Technology Co., Ltd.) at room temperature for $1 \mathrm{~h}$ and probed with primary antibodies for GLUT2 (rabbit polyclonal antibody; 1:200; cat. no. ab54460; Abcam) at $37^{\circ} \mathrm{C}$ for $1 \mathrm{~h}$. Sections were then incubated with anti-rabbit horseradish peroxidase (HRP)-conjugated secondary antibody (1:1; cat. no. PV-6001; OriGene Technologies, Inc.) for $20 \mathrm{~min}$ at $37^{\circ} \mathrm{C}$ and stained using a DAB kit (cat. no. ZLI-9018; OriGene Technologies, Inc.) according to the manufacturer's protocols. Morphology was assessed using a light microscope (magnification, $\mathrm{x} 400$ ) over a spherical field of view $0.5 \mathrm{~mm}$ diameter (cat. no. CX31; Olympus Corporation). Negative controls were included in each sample by substituting primary antibody with PBS. Image Pro Plus (version 6.0; Media Cybernetics, Inc.) was used to quantify the staining. For quantification of staining, using the 'segmentation' function, the measurement threshold in Hue-Saturation-Intensity pattern was selected manually (hue, 0-30 nm; saturation, 0-255 nm; intensity, 1-170 nm), where the integrated optical density was measured.

Immunofluorescence. The pancreas sections were firstly blocked $(1 \%$ BSA $+0.1 \%$ Triton $\mathrm{X}-100$ in PBS) at room temperature for $2 \mathrm{~h}$. Primary antibodies against insulin (rabbit polyclonal antibody; 1:200; cat. no. 4590; Cell Signaling Technology, Inc.) and glucagon (mouse monoclonal antibody; 1:2,000; cat. no. ab10988; Abcam) were added and incubated at $4^{\circ} \mathrm{C}$ overnight. The slides were then incubated with the mixture of fluorophore-conjugated secondary antibodies (fluorescein isothiocyanate labelled goat anti-rabbit, green; and rhodamine labelled goat anti-mouse, red; both 1:2,000; cat. nos. ZF-0311 and ZF-0313, respectively; both OriGene Technologies, Inc.) at room temperature for $2 \mathrm{~h}$, followed by incubation with DAPI (cat. no. D-9106; Beijing Biosynthesis Biotechnology Co., Ltd.), for $5 \mathrm{~min}$. A fluorescent microscope (magnification, $\mathrm{x} 400$ ) over a spherical field of view $0.5 \mathrm{~mm}$ diameter (Axio Observer A1; Zeiss AG) was used to measure fluorescence and perform histology assessments using the Image $\mathbf{J}$ software (version 1.34.3.67; National Institutes of Health). For quantification, fluorescent images were converted to 8-bit gray images before the measurement threshold was selected manually and the selected area of interest was measured.

Western blotting. Pancreas, liver and stomach tissues was homogenized in RIPA buffer (cat. no. P0013B; Beyotime Institute of Biotechnology) with proteinase inhibitors. Total protein concentrations was assessed using a bicinchoninic acid Protein Assay kit (cat. no. P0012; Beyotime Institute of Biotechnology) and a microplate reader (M5, MD-SpectraMax; Molecular Devices LLC). Protein extracts were then mixed with loading buffer (cat. no. P0015L; Beyotime Institute of Biotechnology), and $35 \mathrm{mg}$ protein per lane was loaded and separated using SDS-PAGE (10\%) and transferred onto PVDF membranes that were activated using methanol. After blocking with $5 \%$ skimmed milk powder for $2 \mathrm{~h}$ at room temperature, rabbit polyclonal anti-GOAT (cat. no. ab170690), anti-GLUT2 (cat. no. ab54460) and anti-GHSR (cat. no. ab95250; all 1:1,000; all Abcam) and anti-GAPDH primary antibodies (rabbit monoclonal antibody; 1:1,000; cat. no. 5174; Cell Signaling Technology, Inc.) were added and incubated at $4{ }^{\circ} \mathrm{C}$ overnight. Goat HRP-conjugated anti-rabbit IgG $\mathrm{H} \& \mathrm{~L}$ secondary antibody (1:10,000; cat. no. ZB2301; OriGene Technologies, Inc.) was then added and incubated for $1 \mathrm{~h}$ at room temperature. The protein bands were developed using the Immobilon Western Chemiluminescent Substrate (cat. no. WBKLS0100; EMD Millipore). The intensity of bands was analyzed using Quantity One software (version 4.5.0; Bio-Rad Laboratories, Inc.).

Statistical analysis. Data are expressed as the mean \pm SEM from three independent repeats. Differences between two groups were compared using one-way ANOVA. The LSD (least significance difference) test was used as the post-hoc test. Cumulative food intake and body weight data measured repeatedly were assessed using a mixed two-way ANOVA followed by Sidak post hoc test. All statistical analysis was performed using SPSS software (version 22.0; IBM Corp.). $\mathrm{P}<0.05$ was considered to indicate a statistically significant difference.

\section{Results}

HBO suppresses the elevation of cumulative food intake and fasting blood glucose levels in the T1DM mouse model. Establishment of the T1DM model in the mice was evaluated by observing their feeding behaviour, blood glucose and body weights. Mice exhibiting random blood glucose $\geq 16.7 \mathrm{mmol} / 1$ were considered to be T1DM.

After HBO treatment, the 12-h nocturnal cumulative food intake (Day 12; T1DM vs. CON, $14.47 \pm 1.99$ vs. $5.30 \pm 0.31 \mathrm{~g}$; $\mathrm{P}<0.05$; Fig. 1A), 10-h fasting blood glucose levels (Day 14; T1DM vs. CON, $20.40 \pm 2.23$ vs. $6.28 \pm 0.44 \mathrm{mmol} / \mathrm{l} ; \mathrm{P}<0.05$; Fig. 1C) and body weight loss (Day 10; T1DM vs. CON, $22.00 \pm 0.41$ vs. $36.00 \pm 1.27 \mathrm{~g} ; \mathrm{P}<0.05$; Fig. $1 \mathrm{~B}$ ) were significantly greater in the T1DM group compared with those in the CON group. By contrast, HBO treatment was found to significantly reduce hyperphagia, beginning at $1 \mathrm{~h}$ (Day 12; T1DM+HBO vs. T1DM, $1.14 \pm 0.11$ vs. $3.70 \pm 0.24 \mathrm{~g} ; \mathrm{P}<0.05)$, which was sustained for $12 \mathrm{~h}$ (Day 12; T1DM+HBO vs. T1DM, 6.73 $\pm 0.93 \mathrm{~g}$ vs. $14.47 \pm 1.99 \mathrm{~g} ; \mathrm{P}<0.05$; Fig. $1 \mathrm{~A}$ ), in addition to significantly ameliorating hyperglycaemia (Day 14; T1DM+HBO vs. T1DM, $12.30 \pm 1.89$ vs. $20.40 \pm 2.23 \mathrm{mmol} / \mathrm{l}$; $\mathrm{P}<0.05)$ in T1DM mice (Fig. 1A and C). Although HBO did not improve body weight loss significantly in mice in the T1DM group (Day 10; T1DM+HBO vs. T1DM, $24.00 \pm 0.58$ vs. $22.00 \pm 0.41$ g; Fig. 1B), there was an increasing trend in the T1DM + HBO group.

HBO treatment protects islet $\beta$-cells and promotes pancreatic GLUT2 protein expression levels in T1DM mice. Islet $\beta$-cell destruction is a primary feature of T1DM. To 

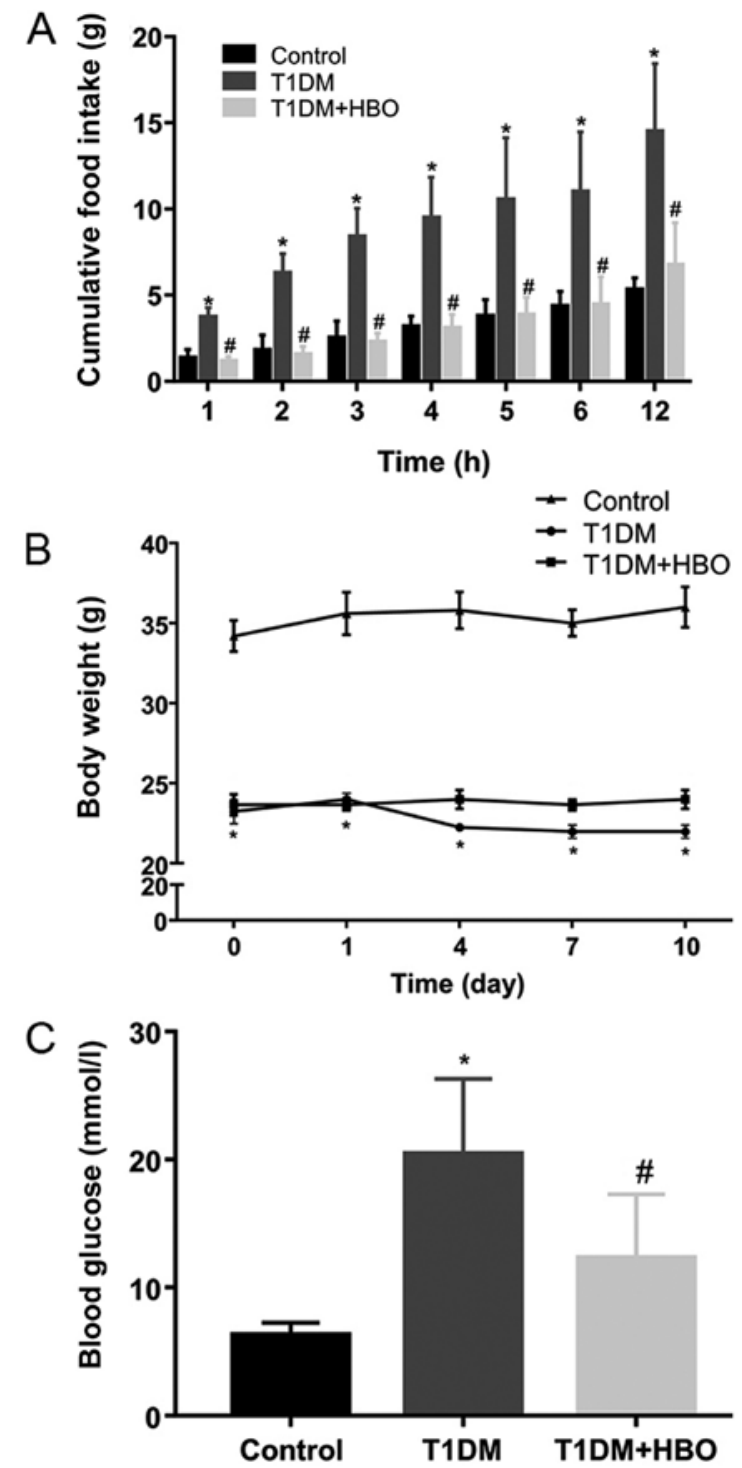

Figure 1. Effect of 2-week HBO treatment on blood glucose, food intake and body weight. (A) Following 5-h food deprivation, cumulative food intake levels were lower in the T1DM + HBO group compared with those in the T1DM group. (B) HBO treatment partially halted body weight decline induced by T1DM. Day 0: 7 days after STZ injection. (C) HBO treatment for 2 weeks significantly reduced T1DM mouse 10-h fasting blood glucose levels, though the blood glucose levels remained higher compared with those in control mice. Data are presented as the mean \pm SEM. ${ }^{*} \mathrm{P}<0.05$ vs. Control and ${ }^{\#} \mathrm{P}<0.05$ vs. T1DM. HBO, hyperbaric oxygen; T1DM, type 1 diabetes mellitus.

investigate the therapeutic effects of $\mathrm{HBO}$ further, insulinand glucagon-positive areas in the pancreas were measured. Compared with that in $\mathrm{CON}$ mice, pancreatic islet $\beta$-cell area in T1DM mice was significantly decreased (T1DM vs. CON, $0.13 \pm 0.01$ vs. $0.89 \pm 0.01 ; \mathrm{P}<0.05$; Fig. $2 \mathrm{~A}$ and $\mathrm{C}$ ) whereas the islet $\alpha$-cell area was significantly increased (T1DM vs. CON, $0.87 \pm 0.01$ vs. $0.11 \pm 0.01 ; \mathrm{P}<0.05$; Fig. $2 \mathrm{~A}$ and $\mathrm{B}$ ). Following 2 -week HBO treatment, $\beta$-cell area in tissues from T1DM mice was partially but significantly increased (T1DM + HBO vs. T1DM, $0.23 \pm 0.03$ vs. $0.13 \pm 0.01 ; \mathrm{P}<0.05)$ and $\alpha$-cell area was likewise partially but significantly reduced (T1DM + HBO vs. T1DM, $0.77 \pm 0.03$ vs. $0.87 \pm 0.01$; $\mathrm{P}<0.05$; Fig. $2 \mathrm{~A}-\mathrm{C}$ ) Reductions in pancreatic GLUT2 expression levels in T1DM mice were also significantly ameliorated by HBO treatment
(T1DM + HBO vs. T1DM, $1.04 \pm 0.05$ vs. $0.69 \pm 0.10 ; \mathrm{P}<0.05$; Fig. 2D), consistent with increased islet $\beta$-cell area.

HBO enhances hepatic glycogen storage and inhibits hepatic GLUT2 membrane trafficking in TIDM mice. To determine if the liver serves a key role in T1DM, glycogen levels were measured as a proxy for the capacity for glycogen storage in the liver. The present study demonstrated significantly lower extent of glycogen storage in T1DM mice compared with that in the CON group, whilst HBO treatment restored hepatic glycogen storage (Fig. 3A). To investigate glucose metabolism further, hepatic GLUT2 expression and membrane trafficking levels were measured. Total hepatic GLUT2 expression levels were not found to be significantly altered between T1DM group and CON group, and HBO did not change T1DM hepatic total GLUT2 expression (Fig. 3D), whereas immunohistochemistry demonstrated that transfer of GLUT2 to the membrane was greater in the T1DM group compared with that in the CON

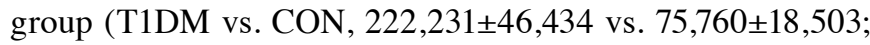
$\mathrm{P}<0.05)$. HBO treatment reversed this increase (T1DM + HBO vs. T1DM, 71,831 $\pm 16,244$ vs. $222,231 \pm 46,434 ; \mathrm{P}<0.05$; Fig. 3B and C).

HBO elevates plasma ghrelin and gastric GOAT protein expression levels in T1DMmice. Total ghrelin levels in the $\mathrm{HBO}$ group were found to be significantly greater compared with those in mice in the T1DM and CON groups (T1DM + HBO vs. T1DM and CON, 16,389.17 \pm 906.31 vs. 9,554.98 $\pm 1,200.69$ and 9,469.76 $\pm 857.22 \mathrm{pg} / \mathrm{ml}$, respectively; $\mathrm{P}<0.05$; Fig. 4A). The gastric GOAT expression levels in the T1DM group were significantly lower compare with those in the CON group (T1DM vs. CON, $0.52 \pm 0.05$ vs. $0.91 \pm 0.03$; $\mathrm{P}<0.05$ ), which was restored by $\mathrm{HBO}$ treatment (T1DM + HBO vs. T1DM, $1.02 \pm 0.09$ vs. $0.52 \pm 0.05 ; \mathrm{P}<0.05)$ to a normal level $(\mathrm{T} 1 \mathrm{DM}+$ HBO vs. CON $1.02 \pm 0.09$ vs. $0.91 \pm 0.03$; P>0.05; Fig. 4B).

HBO promotes pancreatic GOAT expression and downregulates hepatic GHSR expression levels in T1DM mice. In order to investigate the role of the ghrelin system in the changes observed thus far, GOAT and GHSR expression levels were subsequently measured in the pancreas and liver. Pancreatic GOAT expression in the T1DM group was not significantly changed compared with that in the CON group (T1DM vs. CON, $0.94 \pm 0.09$ vs. $1.24 \pm 0.08$; P>0.05; Fig. $5 \mathrm{~A}$ ) but showed a decreasing trend. Pancreatic GOAT expression in the T1DM group was significantly reversed by $\mathrm{HBO}$ treatment (T1DM+HBO vs. T1DM; $1.30 \pm 0.05$ vs. $0.94 \pm 0.09 ; \mathrm{P}<0.05$; Fig. 5A). No significant difference in pancreatic GHSR expression levels was observed among these three groups (T1DM + HBO vs. T1DM vs. CON, $1.07 \pm 0.06$ vs. $1.05 \pm 0.10$ vs. $1.09 \pm 0.15$; Fig. $5 B)$. In addition, no significant differences could be observed between T1DM group and CON group in terms of hepatic GOAT expression. HBO did not change T1DM hepatic GOAT expression, though the GOAT expression levels in $\mathrm{HBO}+\mathrm{T} 1 \mathrm{DM}$ group exhibited a decreasing trend (Fig. 6A). HBO treatment resulted in significantly lower hepatic GHSR protein expression levels compared with those in both the CON and T1DM groups (T1DM + HBO vs. CON and T1DM, $0.67 \pm 0.05$ vs. $0.93 \pm 0.05$ and $0.91 \pm 0.02$, respectively; both $\mathrm{P}<0.05$; Fig. $6 \mathrm{~B}$ ). 

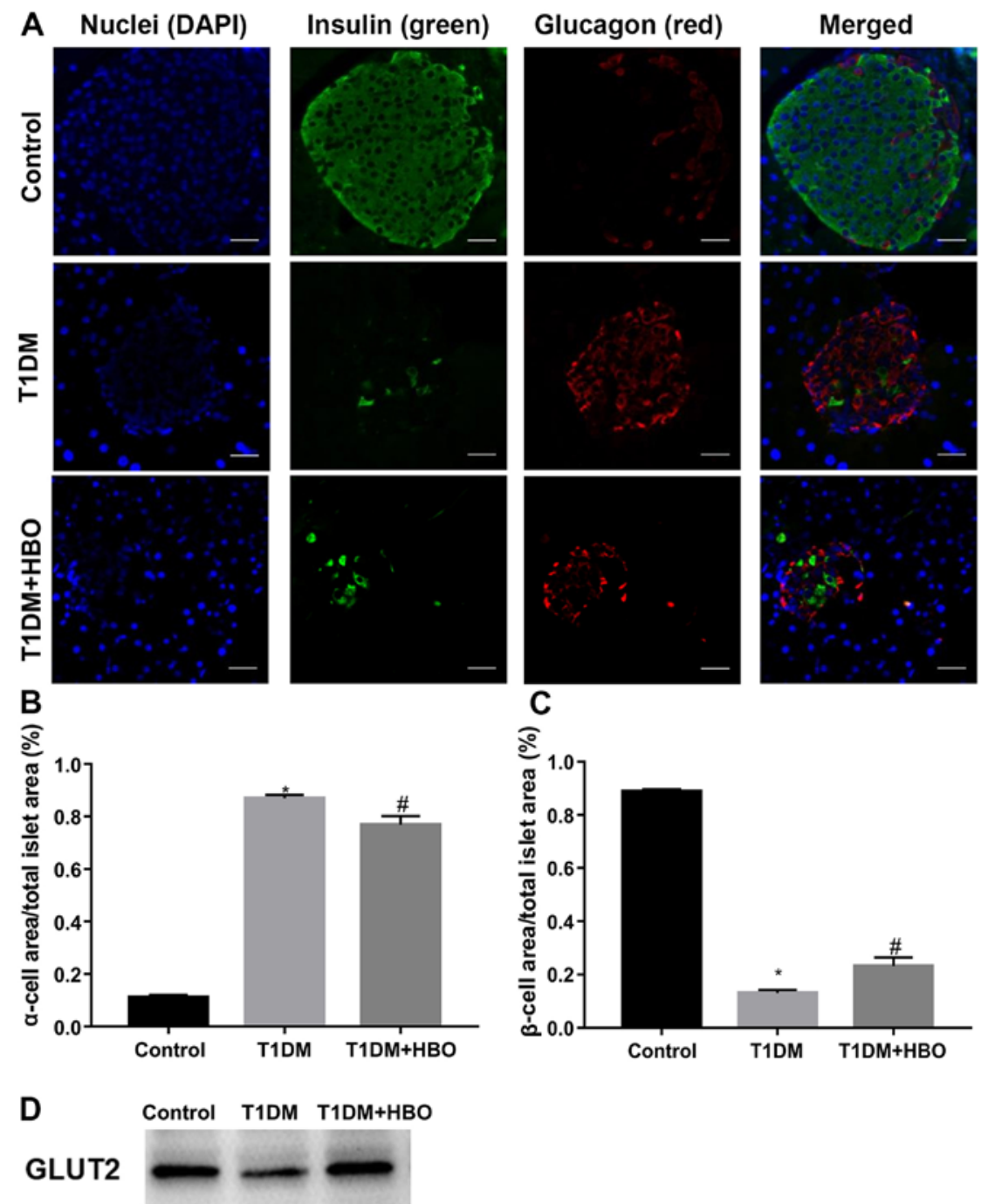

\section{GAPDH}

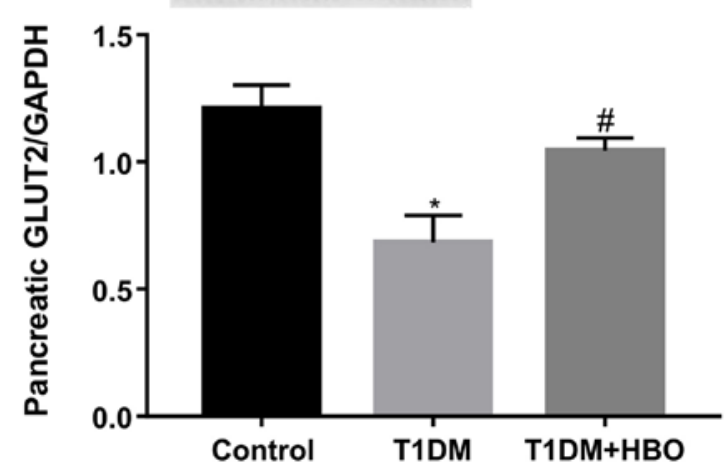

Figure 2. Double staining of insulin and glucagon in pancreatic islets and pancreatic GLUT2 expression levels after HBO treatment. (A) Representative double-immunofluorescence images showing insulin (green), glucagon (red) staining, where the nuclei were counterstained with DAPI in blue. Scale bar, $50 \mu \mathrm{m}$. (B) $\alpha$-cell area was calculated based on glucagon-positive areas. The ratio of $\alpha$-cell area to total islets area was decreased following 2 -week HBO treatment. (C) $\beta$-cell area was calculated based on insulin-positive areas. Quantification of islet area was calculated based on insulin- and glucagon-positive areas. The ratio of islet $\beta$-cell area to total islet area was increased following 2-week HBO treatment. (D) T1DM mouse pancreatic GLUT2 expression levels were decreased, which were reversed by $\mathrm{HBO}$ treatment. Data are presented as the mean \pm SEM. ${ }^{*} \mathrm{P}<0.05$ vs. Control and ${ }^{\#} \mathrm{P}<0.05$ vs. T1DM. GLUT2, glucose transporter 2; HBO, hyperbaric oxygen; T1DM, type 1 diabetes mellitus.

\section{Discussion}

HBO is commonly used to treat diabetic foot ulcers and neuropathy in patients with diabetes mellitus $(39,40)$. Treatment involves intermittent administration of $100 \%$ oxygen, usually in daily sessions of 60-90 min, at pressures of 1.5-3.0 ATA $(41,42)$. In the present study, a 2-week course of HBO-100\% (60-min at 2.0 ATA daily) treatment improved diabetic symptoms in 

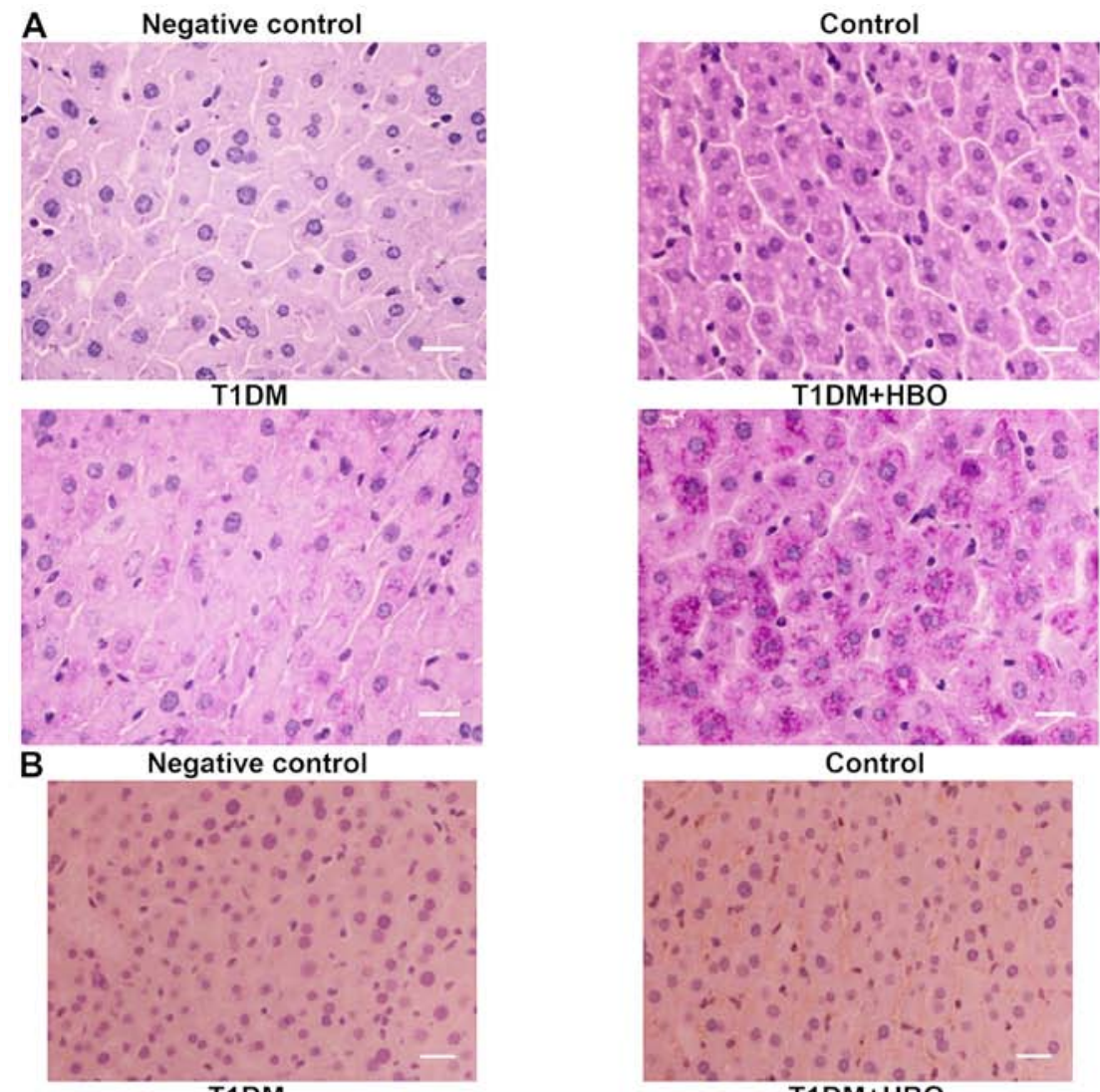

Control
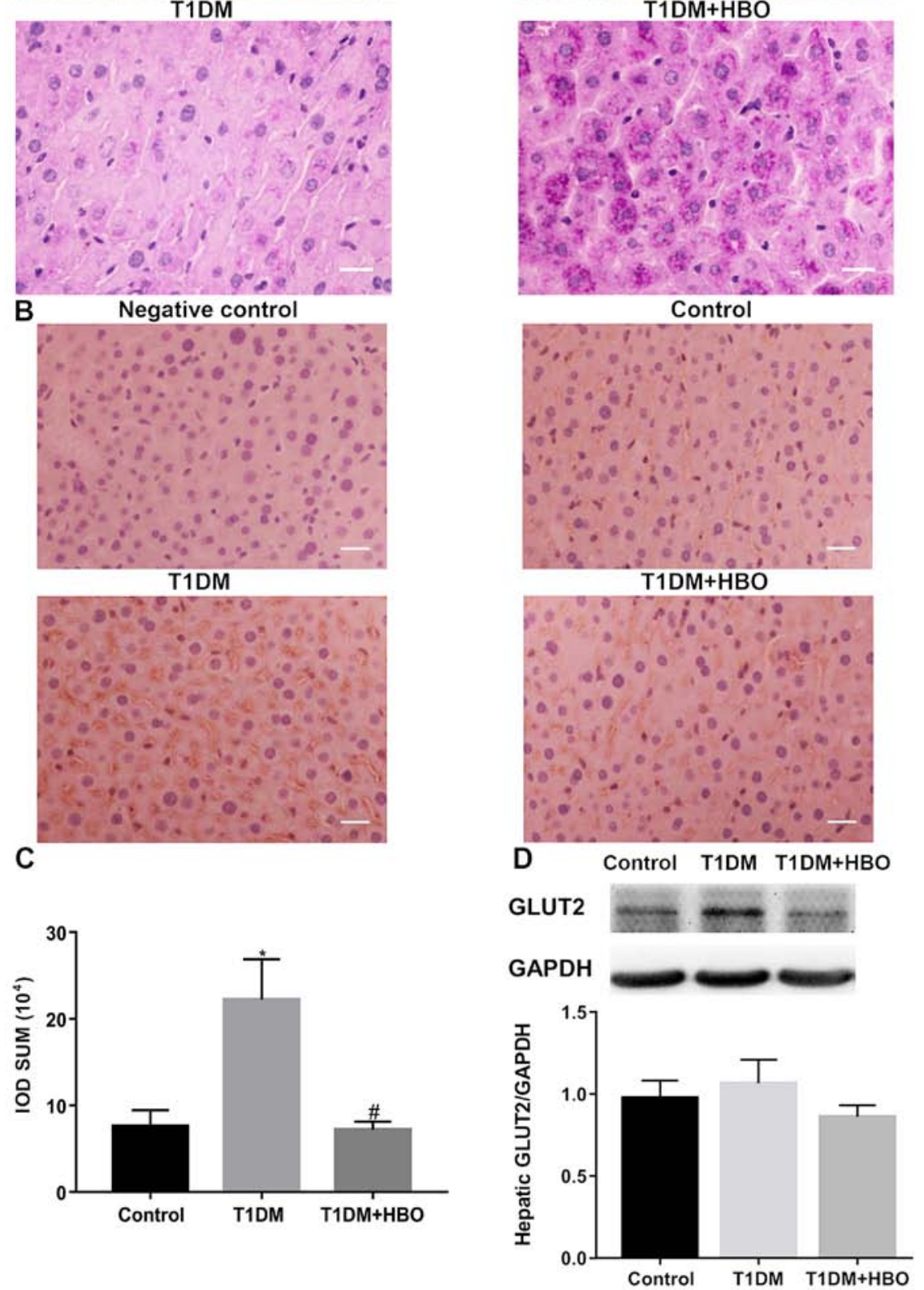

Figure 3. Effect of 2-week HBO treatment on hepatic glycogen storage and GLUT2 expression in the liver. (A) Representative images of periodic acid-Schiff staining. HBO treatment increased the density of PAS-positive spots in T1DM mice. Scale bar, $50 \mu \mathrm{m}$. (B) Representative immunohistochemistry images of hepatic GLUT2 expression levels in the membrane. Scale bar, $50 \mu \mathrm{m}$. (C) Hepatic GLUT2 expression levels in the membrane were greater in T1DM mice and lower in mice treated with HBO. (D) Hepatic cell total GLUT2 expression levels did not change. Negative controls were included in each sample by substituting primary antibody with PBS. Data are presented as the mean \pm SEM. "P $<0.05$ vs. Control and ${ }^{\#} \mathrm{P}<0.05$ vs. T1DM. HBO, hyperbaric oxygen; GLUT2, glucose transport 2; T1DM, type 1 diabetes mellitus; IOD SUM, integral optical density summation.

STZ-induced T1DM mice, as demonstrated by the lower blood glucose levels and 12-h accumulative food intake. A previous study showed that HBO influences the immune system, by increasing resting $\mathrm{T}$ cells and reducing activation of dendritic cells, to prevent autoimmune diabetes (12). Therefore, the present study primarily focused on the regulation of glucose metabolism by HBO. HBO significantly increased the ratio of islet $\beta$-cell area to total islet area, whilst lowering the ratio of $\alpha$-cell area to total islet area. Furthermore, HBO upregulated GLUT2 expression levels, consistent with the increased $\beta$-cell 


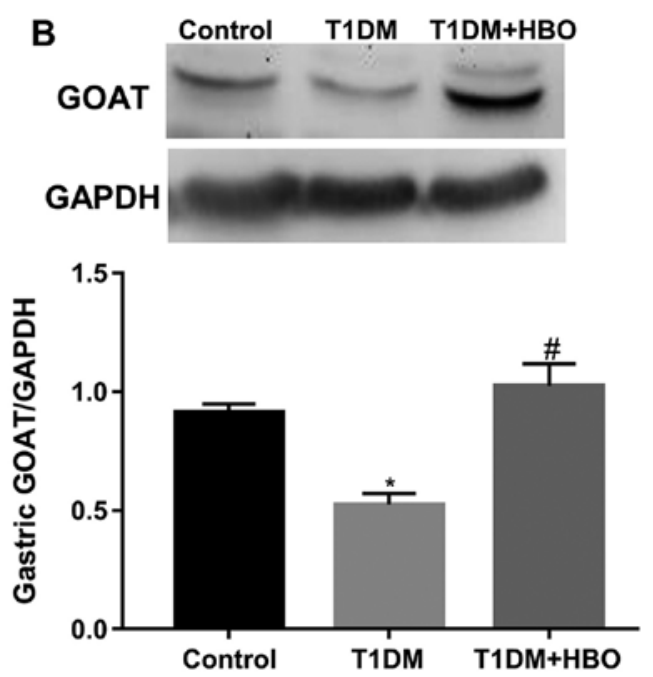

Figure 4. Effect of 2-week HBO treatment on plasma ghrelin and gastric GOAT expression levels. (A) HBO treatment increased plasma total ghrelin levels. (B) Gastric GOAT expression levels were reduced by T1DM induction, which was reversed by HBO treatment. Data are presented as the mean \pm SEM. ${ }^{*} \mathrm{P}<0.05$ vs. Control and ${ }^{\#} \mathrm{P}<0.05$ vs. T1DM. HBO, hyperbaric oxygen; GOAT, ghrelin-O-acyl transferase; T1DM, type 1 diabetes mellitus.
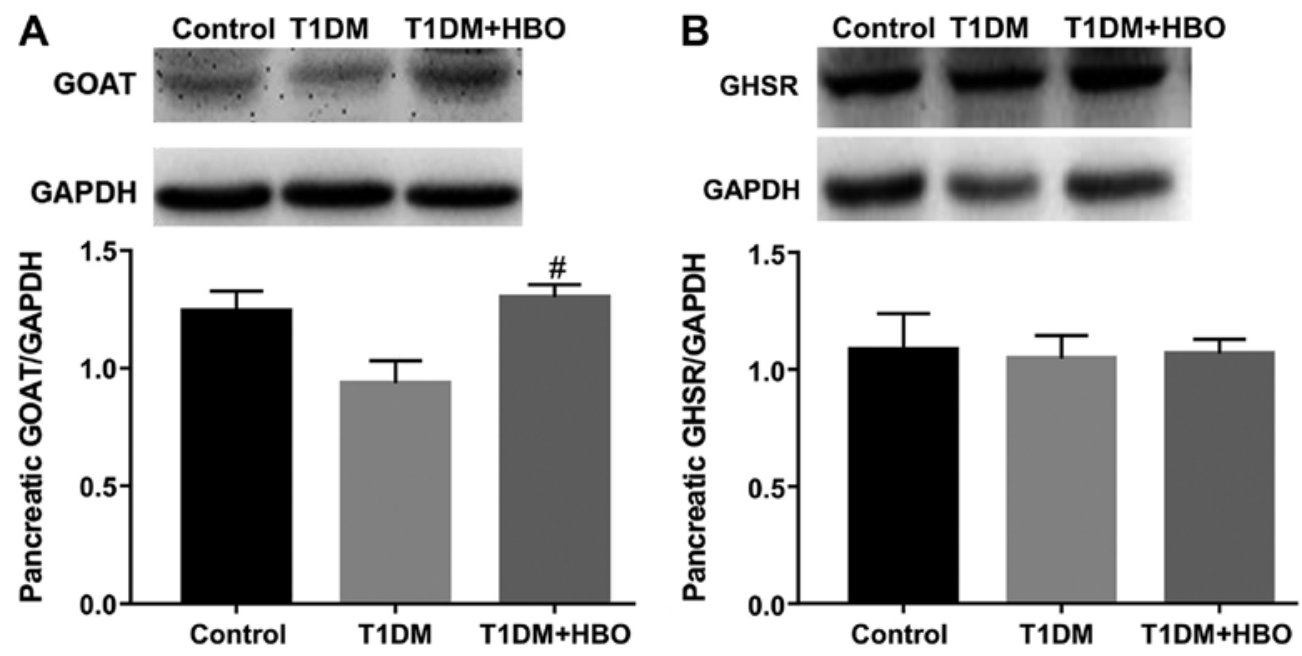

Figure 5. Effect of 2-week HBO treatment on GOAT and GHSR expression in the pancreas. Mouse pancreatic (A) GOAT and (B) GHSR expression levels. ${ }^{\#} \mathrm{P}<0.05$ vs. T1DM. HBO, hyperbaric oxygen; GOAT, ghrelin-O-acyl transferase; GHSR, growth hormone secretagogue receptor-1a; T1DM, type 1 diabetes mellitus.

area, since GLUT2 is not expressed in islet $\alpha$-cells (43). The increased $\beta$-cell area and GLUT2 expression levels in the pancreas isolated from the T1DM + HBO group suggested that insulin-release and glucose-sensing was improved, consistent with the observed blood glucose level alterations following HBO treatment. Previous studies have demonstrated that GLUT2 expression levels are lower in islet $\beta$-cells, but not in the liver tissue, during diabetes $(43,44)$. In the present study, although hepatic GLUT2 expression levels did not change among the three groups, transfer of GLUT2 to the membrane was greater in the T1DM group, which was reversed by $\mathrm{HBO}$ treatment. HBO improved hyperglycemia in the T1DM + HBO group by increasing hepatic glycogen storage and reducing the transfer of GLUT2 to the membrane.

The present study also observed elevated plasma total ghrelin levels with increased gastric expression levels of GOAT in the T1DM + HBO group, suggesting that serum ghrelin levels increased following 2 weeks of HBO treat- ment. However, there was no difference in plasma total ghrelin levels between T1DM and control groups. It has previously been demonstrated that plasma ghrelin concentrations are increased in non-re-feeding STZ-treated rats (45) whereas ghrelin levels assessed following fasting were lower in patients with T1DM (46). These findings suggest that the changes in ghrelin levels in response to diet during diabetes condition is varied. Ghrelin in the circulatory system primarily originates from the stomach and is unstable in the circulation (47). It has previously been reported that gastric GOAT mRNA levels are correlated with circulating ghrelin levels in fasted and diet-induced obese mice (48). Therefore, both total plasma ghrelin levels and gastric GOAT levels were correlate with plasma ghrelin levels, which indicated that plasma ghrelin levels increased after HBO treatment. Ghrelin is deacylated by esterases into des-acyl ghrelin (DAG) in the circulation (47) and re-acylated locally by plasma membrane-resident GOAT (49). Re-acylation of ghrelin in the 
A
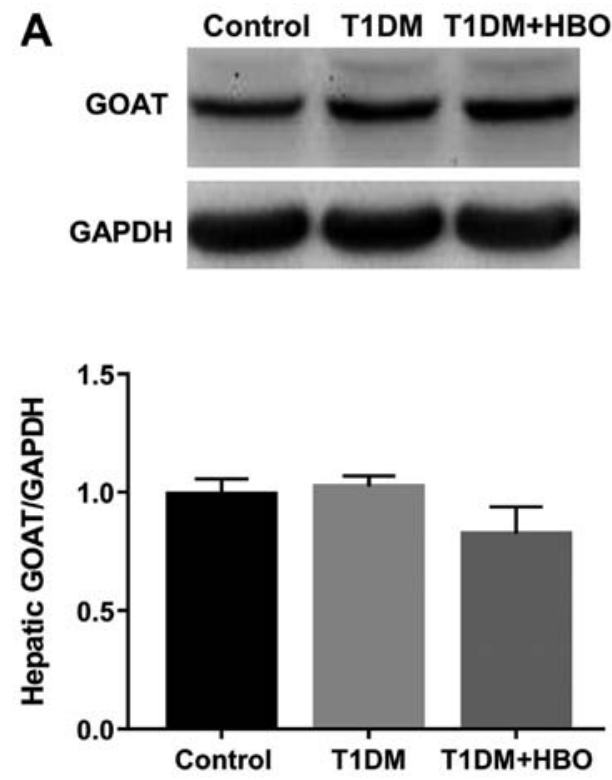

B
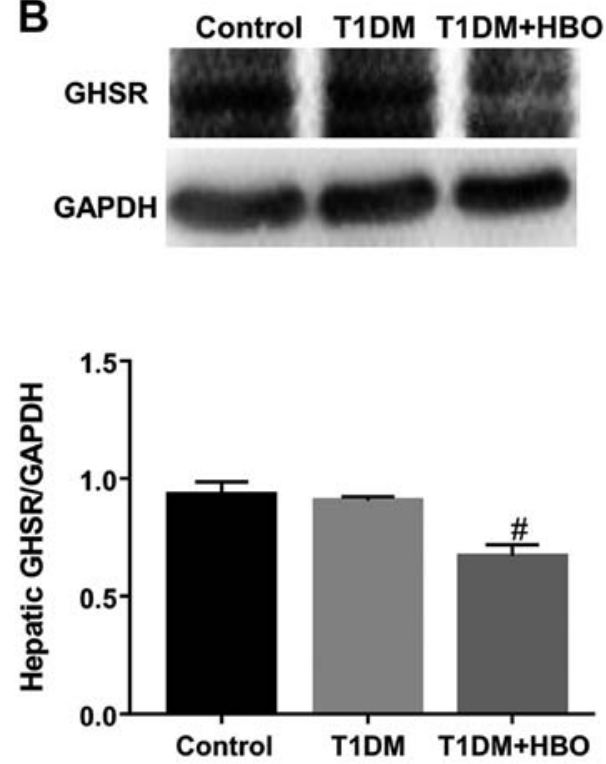

Figure 6. Effects of 2-week HBO treatment on GOAT and GHSR expression levels in the liver. Mouse hepatic (A) GOAT and (B) GHSR expression levels. Data are presented as the mean \pm SEM. ${ }^{\#} \mathrm{P}<0.05$ vs. T1DM. HBO, hyperbaric oxygen; GOAT, ghrelin-O-acyl transferase; GHSR, growth hormone secretagogue receptor-1a; T1DM, type 1 diabetes mellitus.

pancreas and liver was investigated in the current study, and it was found that HBO upregulated pancreatic GOAT expression without affecting hepatic GOAT expression. Ghrelin demonstrated a protective role in islet $\beta$-cells (31), such that HBO increased pancreatic GOAT expression levels in T1DM mice in the present study. Despite the fact that pancreatic GHSR expression levels did not change, the increased GOAT expression levels suggested that ghrelin activity was greater following HBO treatment in T1DM mice. The gene encoding GHSR has been demonstrated to be highly expressed and enriched in islet $\delta$-cells rather than $\alpha$ - and $\beta$-cells (50), which may explain why pancreatic GHSR levels did not change among all groups.

Ghrelin increases blood glucose levels not only via stimulatory effects on food intake and GH secretion, but also by decreasing insulin secretion and increasing circulating levels of glucocorticoids, glucagon release and hepatic gluconeogenesis (19,51-54). Increased serum ghrelin level, lower blood glucose levels and food intake were observed in mice in the T1DM + HBO group. A potential explanation is that the enhanced ghrelin activity could've exerted anti-inflammatory effects on the pancreas (32), but not to a level sufficient to trigger feeding behavior. McFarlane et al (55) previously demonstrated that stimulating food intake in mice via exogenous injection of ghrelin notably increased plasma ghrelin levels. Due to the protection of islet $\beta$-cells by HBO, increased insulin levels could be one reason food intake was decreased in the T1DM + HBO group, while insulin could influence food intake (56). Ghrelin-induced protection of islet $\beta$-cells may exceed the effect of ghrelin on decreased insulin release, increased glucagon secretion and elevation of blood glucose levels via the central nervous system. In addition, reduced hepatic GHSR expression levels following HBO treatment is consistent with the altered blood glucose levels and the effect of ghrelin on hepatic gluconeogenesis (54). Following HBO treatment, plasma ghrelin levels are increased and hepatic
GHSR expression levels may compensate by decreasing. In the present study, it was found that HBO upregulated total plasma ghrelin (ghrelin and DAG) levels. DAG has been previously demonstrated to inhibit ghrelin-induced glucose output in hepatocytes and prevent the hyperglycaemic effects of ghrelin (57), which may be one of the causes of HBO-induced decrease in blood glucose. Bando et al (31) demonstrated that elevating mouse pancreatic ghrelin levels only stimulated $\beta$-cell proliferation, with the serum insulin levels increasing, following $\beta$-cell injury. Chronic hyperglycaemia involves decreased numbers of insulin-positive cells and increased numbers of glucagon-positive cells in islets (58). HBO decreases islet $\beta$-cell apoptosis and increases proliferation (12), thereby decreasing blood glucose levels by improving pancreatic islet structure and function.

The present study investigated the therapeutic effects of HBO on T1DM mice. The results revealed the protective effects of HBO treatment against STZ-induced glucose metabolism dysfunction, in addition to the involvement of the ghrelin system. Further experiments are required to assess the effects of $\mathrm{HBO}$ treatment on $\mathrm{CON}$ mice. However, interventions such as blocking the action of ghrelin (e.g. using a GHSR antagonist or ghrelin/GHSR knockout mice) and measuring the DAG and LEAP2 expression levels were not performed due to the limited capacity of animal housing and handling. These interventions require further investigation.

\section{Acknowledgements}

Not applicable.

\section{Funding}

The present work was supported by the National Natural Science Foundation of China (grant no. 31872791) and 
Natural Science Foundation of Shandong Province of China (grant no. ZR2019MC046).

\section{Availability of data and materials}

The datasets used and/or analysed during the current study are available from the corresponding author on reasonable request.

\section{Authors' contributions}

JD, LS and JY conceptualized and designed the study. LS, JY, YuL, DZ, CZ, QL, ML, KS, RM, YaL and GG performed the experiments. LS and JY analysed the data and wrote the manuscript. JD, RM, LS and JY edited the manuscript. All authors read and approved the final manuscript.

\section{Ethics approval and consent to participate}

All procedures were approved by the Ethics Committee of the Affiliated Hospital of Qingdao University (approval no. QYFYWZLL25600) and performed in accordance with the National Institutes of Health guidelines.

\section{Patient consent for publication}

Not applicable.

\section{Competing interests}

The authors declare that they have no competing interests.

\section{References}

1. Bluestone JA, Herold K and Eisenbarth G: Genetics, pathogenesis and clinical interventions in type 1 diabetes. Nature 464 1293-1300, 2010.

2. Skyler JS and Ricordi C: Stopping type 1 diabetes: Attempts to prevent or cure type 1 diabetes in man. Diabetes 60: 1-8, 2011

3. Xu X, Yi H, Kato M, Suzuki H, Kobayashi S, Takahashi H and Nakashima I: Differential sensitivities to hyperbaric oxygen of lymphocyte subpopulations of normal and autoimmune mice. Immunol Lett 59: 79-84, 1997.

4. Kang N, Hai Y, Yang J, Liang F and Gao CJ: Hyperbaric oxygen intervention reduces secondary spinal cord injury in rats via regulation of HMGB1/TLR4/NF- $\mathrm{BB}$ signaling pathway. Int J Clin Exp Pathol 8: 1141-1153, 2015.

5. Tepić S, Petković A, Srejović I, Jeremić N, Zivković V, Loncarević S, Bradić J, Jakovljević V and Zivkovć M: Impact of hyperbaric oxygenation on oxidative stress in diabetic patients. Undersea Hyperb Med 45: 9-17, 2018.

6. Lee YS, Chio CC, Chang CP, Wang LC, Chiang PM, Niu KC and Tsai KJ: Long course hyperbaric oxygen stimulates neurogenesis and attenuates inflammation after ischemic stroke. Mediators Inflamm 2013: 512978, 2013.

7. Thom SR, Bhopale VM, Velazquez OC, Goldstein LJ, Thom LH and Buerk DG: Stem cell mobilization by hyperbaric oxygen. Am J Physiol Heart Circ Physiol 290: H1378-H1386, 2006.

8. Al-Waili NS, Butler GJ, Beale J, Abdullah MS, Finkelstein M, Merrow M, Rivera R, Petrillo R, Carrey Z, Lee B and Allen M: Influences of hyperbaric oxygen on blood pressure, heart rate and blood glucose levels in patients with diabetes mellitus and hypertension. Arch Med Res 37: 991-997, 2006.

9. Stevens SL, Sorita A, Narr AJ, Claus PL, Tescher A, Millman MP, Shields RC, Buchta WG, Haddon R and Murad MH: Applying quality improvement methods in a hyperbaric oxygen program: Reducing unnecessary glucose testing. Undersea Hyperb Med 43: 427-435, 2016.
10. Nagatomo F, Takemura A, Roy RR, Fujino H, Kondo H and Ishihara A: Mild hyperbaric oxygen inhibits the growth-related decline in skeletal muscle oxidative capacity and prevents hyperglycemia in rats with type 2 diabetes mellitus. J Diabetes 10: 753-763, 2018.

11. Gu N, Nagatomo F, Fujino H, Takeda I, Tsuda K and Ishihara A: Hyperbaric oxygen exposure improves blood glucose level and muscle oxidative capacity in rats with type 2 diabetes. Diabetes Technol Ther 12: 125-133, 2010.

12. Faleo G, Fotino C, Bocca N, Molano RD, Zahr-Akrawi E, Molina J, Villate S, Umland O, Skyler JS, Bayer AL, et al: Prevention of autoimmune diabetes and induction of beta-cell proliferation in NOD mice by hyperbaric oxygen therapy. Diabetes 61: 1769-1778, 2012

13. Roden $M$ and Bernroider E: Hepatic glucose metabolism in humans-its role in health and disease. Best Pract Res Clin Endocrinol Metab 17: 365-383, 2003.

14. Mani BK and Zigman JM: Ghrelin as a survival hormone. Trends Endocrinol Metab 28: 843-854, 2017.

15. Ge X, Yang H, Bednarek MA, Galon-Tilleman H, Chen P, Chen M, Lichtman JS, Wang Y, Dalmas O, Yin Y, et al: LEAP2 Is an endogenous antagonist of the ghrelin receptor. Cell Metab 27: 461-469.e6, 2018.

16. Date Y, Kojima M, Hosoda H, Sawaguchi A, Mondal MS, Suganuma T, Matsukura S, Kangawa K and Nakazato M: Ghrelin, a novel growth hormone-releasing acylated peptide, is synthesized in a distinct endocrine cell type in the gastrointestinal tracts of rats and humans. Endocrinology 141: 4255-4261, 2000.

17. Kojima M, Hosoda H, Date Y, Nakazato M, Matsuo H and Kangawa K: Ghrelin is a growth-hormone-releasing acylated peptide from stomach. Nature 402: 656-660, 1999.

18. Yang J, Brown MS, Liang G, Grishin NV and Goldstein JL: Identification of the acyltransferase that octanoylates ghrelin, an appetite-stimulating peptide hormone. Cell 132: 387-396, 2008.

19. Zhao TJ, Liang G, Li RL, Xie X, Sleeman MW, Murphy AJ, Valenzuela DM, Yancopoulos GD, Goldstein JL and Brown MS: Ghrelin O-acyltransferase (GOAT) is essential for growth hormone-mediated survival of calorie-restricted mice. Proc Natl Acad Sci USA 107: 7467-7472, 2010.

20. Pereira JADS, da Silva FC and de Moraes-Vieira PMM: The Impact of Ghrelin in Metabolic Diseases: An Immune Perspective. J Diabetes Res 2017: 4527980, 2017.

21. Mao Y, Tokudome T, Kishimoto I, Otani K, Nishimura H, Yamaguchi O, Otsu K, Miyazato M and Kangawa K: Endogenous ghrelin attenuates pressure overload-induced cardiac hypertrophy via a cholinergic anti-inflammatory pathway. Hypertension 65: 1238-1244, 2015.

22. Li G, Liu J, Xia WF, Zhou CL and Lv LQ: Protective effects of ghrelin in ventilator-induced lung injury in rats. Int Immunopharmacol 52: 85-91, 2017.

23. Hossienzadeh F, Babri S, Alipour MR, Ebrahimi $\mathrm{H}$ and Mohaddes G: Effect of ghrelin on brain edema induced by acute and chronic systemic hypoxia. Neuroscience Lett 534: 47-51, 2013.

24. Mohaddes G, Abdolalizadeh J, Babri S, Abedini N and Hossienzadeh F: The anti-edematous effect of ghrelin in brain hypoxia is associated with decreasing expression of vascular endothelial growth factor. J Mol Neurosci 56: 273-277, 2015.

25. Heppner KM and Tong J: Mechanisms in endocrinology: Regulation of glucose metabolism by the ghrelin system: Multiple players and multiple actions. Eur J Endocrinol 171: R21-R32, 2014.

26. An W, Li Y, Xu G, Zhao J, Xiang X, Ding L, Li J, Guan Y, Wang X, Tang C, et al: Modulation of ghrelin O-acyltransferase expression in pancreatic islets. Cell Physiol Biochem 26: 707-716, 2010.

27. Kim SW, Her SJ, Park SJ, Kim D, Park KS, Lee HK, Han BH, Kim MS, Shin CS and Kim SY: Ghrelin stimulates proliferation and differentiation and inhibits apoptosis in osteoblastic MC3T3-E1 cells. Bone 37: 359-369, 2005.

28. Liang QH, Liu Y, Wu SS, Cui RR, Yuan LQ and Liao EY: Ghrelin inhibits the apoptosis of MC3T3-E1 cells through ERK and AKT signaling pathway. Toxicol Appl Pharmacol 272: 591-597, 2013.

29. Zhu K, Zhang ML, Liu ST, Li XY, Zhong SM, Li F, Xu GZ, Wang $Z$ and Miao Y: Ghrelin attenuates retinal neuronal autophagy and apoptosis in an experimental rat glaucoma model. Invest Ophthalmol Vis Sci 58: 6113-6122, 2017.

30. Hao Y, Liu C, Huang J, Gu Y, Li H, Yang Z, Liu J, Wang W and Li R: Ghrelin protects against depleted uranium-induced apoptosis of MC3T3-E1 cells through oxidative stress-mediated p38-mitogen-activated protein kinase pathway. Toxicol Appl Pharmacol 290: 116-125, 2016. 
31. Bando M, Iwakura H, Ariyasu H, Koyama H, Hosoda K, Adachi S, Nakao K, Kangawa K and Akamizu T: Overexpression of intraislet ghrelin enhances $\beta$-cell proliferation after streptozotocin-induced $\beta$-cell injury in mice. Am J Physiol Endocrinol Metab 305: E140-E148, 2013.

32. Baena-Nieto G, Lomas-Romero IM, Mateos RM, Leal-Cosme N, Perez-Arana G, Aguilar-Diosdado M, Segundo $C$ and Lechuga-Sancho AM: Ghrelin mitigates $\beta$-cell mass loss during insulitis in an animal model of autoimmune diabetes mellitus, the BioBreeding/Worcester rat. Diabetes Metab Res Rev: 33, 2017 doi: $10.1002 / \mathrm{dmrr} .2813$

33. Blanco AM, Bertucci JI, Ramesh N, Delgado MJ, Valenciano AI and Unniappan S: Ghrelin facilitates GLUT2-, SGLT1- and SGLT2-mediated intestinal glucose transport in goldfish (Carassius auratus). Sci Rep 7: 45024, 2017.

34. Fuente-Martín E, García-Cáceres C, Argente-Arizón P, Díaz F, Granado M, Freire-Regatillo A, Castro-González D, Ceballos ML, Frago LM, Dickson SL, et al: Ghrelin regulates glucose and glutamate transporters in hypothalamic astrocytes. Sci Rep 6: 23673, 2016.

35. Li RL, Sherbet DP, Elsbernd BL, Goldstein JL, Brown MS and Zhao TJ: Profound hypoglycemia in starved, ghrelin-deficient mice is caused by decreased gluconeogenesis and reversed by lactate or fatty acids. J Biol Chem 287: 17942-17950, 2012.

36. Zhou XY, Zhang F, Hu XT, Chen J, Tang RX, Zheng KY and Song YJ: Depression can be prevented by astaxanthin through inhibition of hippocampal inflammation in diabetic mice. Brain Res 1657: 262-268, 2017.

37. Liu YN, Yang Z, Kong D, Zhang Y, Yu W and Zha W: Metformin ameliorates testicular damage in male mice with streptozotocin-induced type 1 diabetes through the PK2/PKR Pathway. Oxid Med Cell Longev 2019: 5681701, 2019.

38. Wang R, Yuan J, Zhang C, Wang L, Liu Y, Song L, Zhong W, Chen $X$ and Dong J: Neuropeptide Y-Positive neurons in the dorsomedial hypothalamus are involved in the anorexic effect of angpt18. Front Mol Neurosci 11: 451, 2018.

39. Ma L, Li P, Shi Z, Hou T, Chen X and Du J: A prospective, randomized, controlled study of hyperbaric oxygen therapy: Effects on healing and oxidative stress of ulcer tissue in patients with a diabetic foot ulcer. Ostomy Wound Manage 59: 18-24, 2013.

40. Veyseller B, Dogan R, Yenigun A, Aksoy F, Tugrul S, Dogan EE and Ozturan O: Hyperbaric oxygen therapy of olfactory dysfunction in diabetic neuropathy with type 2 diabetes mellitus and a new definition diabetic olfactopathy. Rhinology 54: 273-277, 2016

41. Stoekenbroek RM, Santema TB, Legemate DA, Ubbink DT, van den Brink A and Koelemay MJ: Hyperbaric oxygen for the treatment of diabetic foot ulcers: A systematic review. Eur J Vasc Endovasc Surg 47: 647-655, 2014.

42. Resanovic I and Gluvic Z: Early Effects of hyperbaric oxygen on inducible nitric oxide synthase activity/expression in lymphocytes of type 1 diabetes patients: A prospective pilot study. Int J Endocrinol 2019: 2328505, 2019.

43. Thorens B: GLUT2, glucose sensing and glucose homeostasis. Diabetologia 58: 221-232, 2015.

44. Párrizas M, Maestro MA, Boj SF, Paniagua A, Casamitjana R, Gomis R, Rivera F and Ferrer J: Hepatic nuclear factor 1-alpha directs nucleosomal hyperacetylation to its tissue-specific transcriptional targets. Mol Cell Biol 21: 3234-3243, 2001
45. Ishii S, Kamegai J, Tamura H, Shimizu T, Sugihara H and Oikawa S: Role of ghrelin in streptozotocin-induced diabetic hyperphagia. Endocrinology 143: 4934-4937, 2002.

46. Nowak N, Hohendorff J, Solecka I, Szopa M, Skupien J, Kiec-Wilk B, Mlynarski W and Malecki MT: Circulating ghrelin level is higher in HNF1A-MODY and GCK-MODY than in polygenic forms of diabetes mellitus. Endocrine 50: 643-649, 2015.

47. Gutierrez JA, Willency JA, Knierman MD, Coskun T, Solenberg PJ, Perkins DR, Higgs RE and Hale JE: From ghrelin to ghrelin's O-acyl transferase. Methods Enzymol 514: 129-146, 2012.

48. Gahete MD, Córdoba-Chacón J, Salvatori R, Castaño JP, Kineman RD and Luque RM: Metabolic regulation of ghrelin $\mathrm{O}$-acyl transferase (GOAT) expression in the mouse hypothalamus, pituitary, and stomach. Mol Cell Endocrinol 317: 154-160, 2010.

49. Hougland JL: Ghrelin octanoylation by ghrelin O-acyltransferase: Unique protein biochemistry underlying metabolic signaling. Biochem Soc Trans 47: 169-178, 2019.

50. Adriaenssens AE, Svendsen B, Lam BY, Yeo GS, Holst JJ, Reimann F and Gribble FM: Transcriptomic profiling of pancreatic alpha, beta and delta cell populations identifies delta cells as a principal target for ghrelin in mouse islets. Diabetologia 59: 2156-2165, 2016.

51. Chuang JC, Sakata I, Kohno D, Perello M, Osborne-Lawrence S, Repa JJ and Zigman JM: Ghrelin directly stimulates glucagon secretion from pancreatic alpha-cells. Mol Endocrinol 25: 1600-1611, 2011.

52. Tong J, Prigeon RL, Davis HW, Bidlingmaier M, Kahn SE, Cummings DE, Tschöp MH and D'Alessio D: Ghrelin suppresses glucose-stimulated insulin secretion and deteriorates glucose tolerance in healthy humans. Diabetes 59: 2145-2151, 2010.

53. Dezaki K, Hosoda H, Kakei M, Hashiguchi S, Watanabe M, Kangawa $\mathrm{K}$ and Yada T: Endogenous ghrelin in pancreatic islets restricts insulin release by attenuating $\mathrm{Ca}^{2+}$ signaling in beta-cells: Implication in the glycemic control in rodents. Diabetes 53: 3142-3151, 2004.

54. Brial F, Lussier CR, Belleville K, Sarret P and Boudreau F: Ghrelin inhibition restores glucose homeostasis in hepatocyte nuclear factor-1 $\alpha$ (MODY3)-Deficient Mice. Diabetes 64: 3314-3320, 2015.

55. McFarlane MR, Brown MS, Goldstein JL and Zhao TJ: Induced ablation of ghrelin cells in adult mice does not decrease food intake, body weight, or response to high-fat diet. Cell Metab 20: 54-60, 2014.

56. Kleinridders A, Ferris HA, Cai W and Kahn CR: Insulin action in brain regulates systemic metabolism and brain function. Diabetes 63: 2232-2243, 2014.

57. Özcan B, Neggers SJ, Miller AR, Yang HC, Lucaites V, Abribat T, Allas S, Huisman M, Visser JA, Themmen AP, et al: Does des-acyl ghrelin improve glycemic control in obese diabetic subjects by decreasing acylated ghrelin levels? Eur J Endocrinol 170: 799-807, 2014

58. Brereton MF, Iberl M, Shimomura K, Zhang Q, Adriaenssens AE, Proks P, Spiliotis II, Dace W, Mattis KK, Ramracheya R, et al: Reversible changes in pancreatic islet structure and function produced by elevated blood glucose. Nat Commun 5: 4639, 2014.

This work is licensed under a Creative Commons Attribution-NonCommercial-NoDerivatives 4.0 International (CC BY-NC-ND 4.0) License. 